\title{
Study on Economics of Peach Cultivation under Different Fertigation Level and Foliar Applications in Tarai region of Uttarakhand, India
}

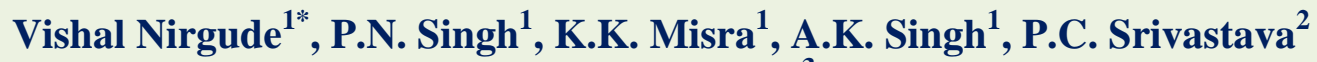 \\ and Atul Kumar ${ }^{3}$
}

${ }^{1}$ Department of Horticulture, ${ }^{2}$ Department of Soil Science, College of Agriculture, G.B. Pant University of Agriculture and Technology, Pantnagar (U.S. Nagar), Uttarakhand, India. ${ }^{3}$ Department of Plant Physiology, College of Basic Sciences and Humanities, G.B. Pant University of Agriculture and Technology, Pantnagar (U.S. Nagar), Uttarakhand, India

*Corresponding author

\section{A B S T R A C T}

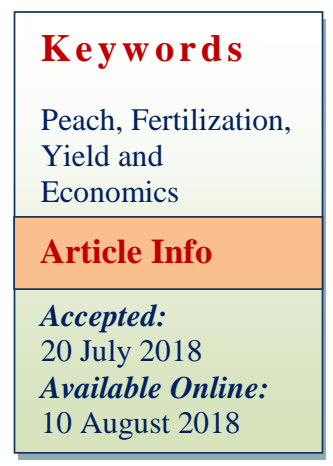

The present study was carried out at Horticultural Research Centre, Patharchatta, G.B. Pant University of Agriculture and Technology Pantnagar, Uttarakhand to find out the most effective combination of NPK fertigation with foliar applications on economic performance of peach during two successive years i.e., 2015 and 2016 in five and six years old peach cv. Shan-e-Punjab. Based on recommended dose of fertilizer (420:240:300g NPK/tree/year) for conventional method, nine treatments were formulated and studied. The obtained results indicate that the maximum yield $(10.61 \mathrm{t} / \mathrm{ha})$ was recorded with $\mathrm{T}_{8}$. Similarly, the total expenditure cost (Rs. 107530.31), gross income (Rs. 530500.00) and net income (Rs. 422969.69) per hectare were found higher under treatments $\mathrm{T}_{8}$, whereas, it was found to be lowest under control $\left(\mathrm{T}_{9}\right)$. Among all the treatments, the benefit: cost ratio was found highest (3.93) under $\mathrm{T}_{8}$, followed by 3.26 in $\mathrm{T}_{4}$, however, it was found lowest (1.21) in $\mathrm{T}_{9}$. Thus, from economic point of view, fertigation dose of $75 \% \mathrm{RDN}+0.5 \%$ Ferrous sulfate $+0.2 \%$ Borax $\left(\mathrm{T}_{8}\right)$ was found to be most suitable in Tarai conditions of Uttarakhand.

\section{Introduction}

Peach [Prunus persica (L.) Batsch] belongs to the family Rosaceae and is one of the important stone fruit grown in temperate part of the world. Introduction of cultivated peaches into India, probably, took place in later half of $19^{\text {th }}$ century. In India, the cultivation of peach is mostly confined to Uttarakhand, Jammu and Kashmir, Himachal
Pradesh, Punjab, Nilgiri and North-Eastern region. Peach along with its close relative nectarine, occupies about an area of 40762 hactare with total production of 287778 tonnes and productivity of $7.17 \mathrm{t} / \mathrm{ha}$ in India (Anonymous, 2016). During the past few years, cultivation of stone fruits, especially peach has become popular in the subtropical climate of North Indian plains. The horticultural produce, besides their high 
nutritional value, help in generation of additional profit and employment through onfarm processing and marketing of fresh produce as well as processed products. The demand for stone fruits and their processed products has increased because of rise in health concerns and nutritional awareness.

The peach crop has been considered as highly sensitive to water and fertilizer applications. The conventional practice of fertilization and irrigation has given detrimental effect on the soil health and quality of produce, besides, poor nutrient and water use efficiency. One of the recent techniques of fertilization is fertigation, in which fertilizers are applied through drip irrigation systems (Bussi et al., 1991), which permits the fertilizer application directly at the site of roots which results in improved fertilizer use efficiency (Singh et al., 2005). Fertilization using such approach has found to improve yield attributes as well as produce quality fruits which fetch high profit from the market.

The economic evaluation of any experiment is very essential, as farmers are convinced with specific recommendation through economic aspect of the research. In recent past, only few studies have been conducted on economic survey of peach orchard (Gangwar et al., 2008 and Gupta et al., 2016), however, study on the economics of peach cultivation under fertigation level and foliar applications are lacking in study area, hence, the present study was conducted to work out the economics of peach cv. Shan-e-Punjab under different treatments.

\section{Materials and Methods}

The present investigation was carried out at the Horticultural Research Centre, Patharchatta, G. B. Pant University of Agriculture and Technology Pantnagar, Uttarakhand to find out the most effective combination of NPK fertigation with foliar application on economic performance of peach during 2015 and 2016 growing seasons. Five and six years old low-chill peach cultivar Shan-e-Punjab, planted at $5 \times 5$ meter, was used for the study. Based on recommended dose of fertilizer (420:240:300g $\mathrm{NPK} /$ tree/year), nine treatments viz., $\left[\mathrm{T}_{1}\right.$ $\left(100 \%\right.$ of $\mathrm{RDN}+0.25 \%$ Ferrous sulfate); $\mathrm{T}_{2}$ ( $75 \%$ of RDN $+0.25 \%$ Ferrous sulfate); $\mathrm{T}_{3}$ $(50 \%$ of RDN $+0.25 \%$ Ferrous sulfate $) ; \mathrm{T}_{4}$ $(75 \%$ of $\mathrm{RDN}+0.25 \%$ Ferrous sulfate + $0.2 \%$ Borax $) ; \mathrm{T}_{5}(100 \%$ of $\mathrm{RDN}+0.5 \%$ Ferrous sulfate); $\mathrm{T}_{6}(75 \%$ of $\mathrm{RDN}+0.5 \%$ Ferrous sulfate); $\mathrm{T}_{7}(50 \%$ of $\mathrm{RDN}+0.5 \%$ Ferrous sulfate); $\mathrm{T}_{8}(75 \%$ of $\mathrm{RDN}+0.5 \%$ Ferrous sulfate $+0.2 \%$ Borax $)$ and $\mathrm{T}_{9}$ (Control)] were formulated. In both the experimental year, the quantity of water soluble fertilizers [(N:P:K (20:20:20), urea, mono potassium phosphate and murate of potash)] were computed based on gram per tree per split requirement. Fertigation of NPK was done through venturi in 10 different split applications at 15 days intervals, starting from $15^{\text {th }}$ December to continue till $30^{\text {th }}$ of April, whereas, in case of control, fertilization was done as per the recommended practice in tree basin using urea, diammonium phosphate and murate of potash. However, the foliar applications of micronutrients ( $\mathrm{Fe}$ and $\mathrm{B}$ ) were performed during appropriate growth stages. The cost of fertilizers varied in different treatment while, other operational charges and inputs were almost same in all other treatments except fertilization cost in control.

The fruits were harvested from each tree during the month of May and yield was expressed in tonnes per hectare. The total expenditure per hectare (Table 1a and 1b) was worked out for all the treatments by adding all the costs (fertilizers and intercultural operations) for the purpose of experiment during two years and the values were 
expressed in rupees. The gross income (Table 2) was worked out after selling the harvested fruits at prevailing market price (Rs. 50 per $\mathrm{kg}$ ), subsequently, the net income (Table 2) was calculated by subtracting the total expenditure from the gross return. Finally, the return per rupees invested i.e., benefit: cost ratio was calculated for all the treatments and compared with conventional method i.e., control. The data regarding fruit yield attributes was subjected to statistical analysis in order to find out the treatment showed significant variation in different under study. The technique of analysis of variance (ANOVA) for randomized block design (RBD) was adopted as per Gomez and Gomez (1984).

\section{Results and Discussion}

The data regarding economics of the experiment (total expenditure, yield, gross income and net income) on the basis of one hactare land, under different treatments have presented in Table 1a and $\mathrm{b}$ and 2 . The careful scrutiny of data indicates that total expenditure was found highest being Rs. 107530.31 in $75 \%$ of RDN $+0.5 \%$ Ferrous sulfate $+0.2 \%$ Borax $\left(\mathrm{T}_{8}\right)$ followed by Rs. 106854.13 in $100 \%$ of RDN $+0.5 \%$ Ferrous sulfate $\left(\mathrm{T}_{4}\right)$, whereas, lowest expenditure (Rs. 75478.71) was calculated in control $\left(\mathrm{T}_{9}\right)$. Similarly, the maximum yield (10.61 t/ha) was recorded in $\mathrm{T}_{8}$ and statistically found significantly superior than rest of the treatments, followed by $(8.91 \mathrm{t} / \mathrm{ha})$ in $\mathrm{T}_{4}$, however, the minimum yield (3.35 t/ha) was recorded in under control tress. Therefore, based on yield obtained in individual treatments, the highest gross income (Rs. 530500.00) was recorded in $\mathrm{T}_{8}$, followed by Rs. 445500.00 in $\mathrm{T}_{4}$, whereas, lowest gross income (Rs. 235500.00) was calculated in $\mathrm{T}_{9}$. Further, after deducting the total expenditure from the gross income of corresponding treatments, the highest net income (Rs. 422969.69) was calculated in $\mathrm{T}_{8}$, whereas it was found lowest (Rs. 92031.28) under $\mathrm{T}_{9}$. Finally, after calculating the all inputs, the benefit: cost ratio (Figure 1) was calculated, which was found maximum (3.93) under $T_{8}$ followed by 3.26 under $\mathrm{T}_{4}$. However, minimum benefit: cost ratio (1.21) was observed in $\mathrm{T}_{9}$ followed by 1.40 in $50 \%$ of $\mathrm{RDN}+0.25 \%$ Ferrous sulfate $\left(\mathrm{T}_{3}\right)$ and 1.50 in $50 \%$ of $\mathrm{RDN}+0.5 \%$ Ferrous sulfate $\left(\mathrm{T}_{7}\right)$.

Figure.1 Benefit: cost ratio analysis of peach cv. Shan-e-Punjab under different treatments during experimental years

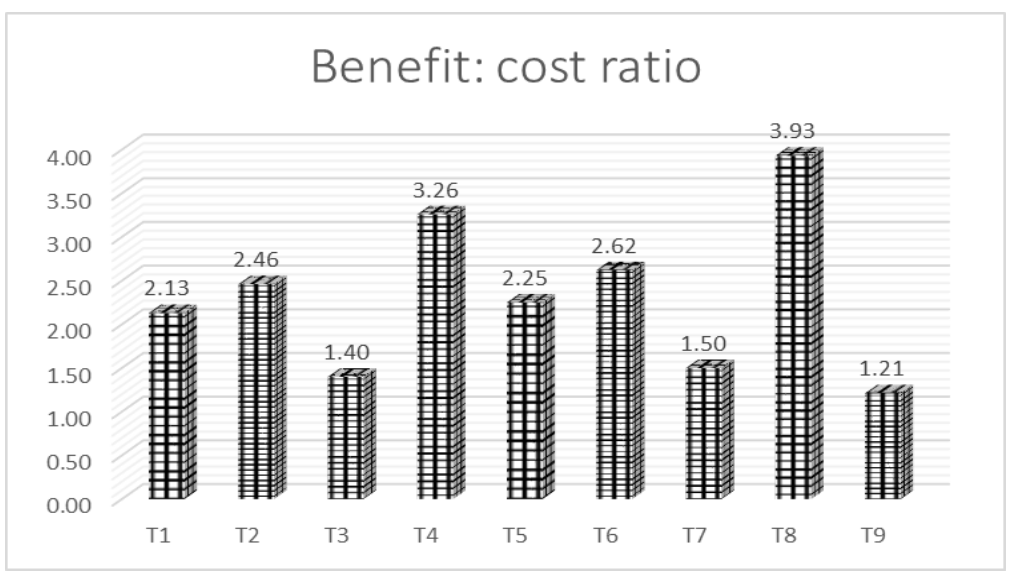


Table.1a Expenditure cost (fertilizer and chemical) of peach cv. Shan-e-Punjab using different fertigation level and foliar applications

\begin{tabular}{|c|c|c|c|c|c|}
\hline Treatments & Fertilizer and chemicals & Quantity (kg) & Unit price (Rs.) & Costs (Rs.) & Total costs (Rs.) \\
\hline \multirow{5}{*}{$100 \%$ of RDN $+0.25 \%$ Ferrous sulfate $\left(\mathrm{T}_{1}\right)$} & Urea (46:00:00) & 191.30 & 6.0 & 1147.83 & \multirow[t]{5}{*}{32412.14} \\
\hline & NPK $(20: 20: 20)$ & 80.00 & 230.0 & 18400.00 & \\
\hline & MPK (00:52:34) & 30.77 & 357.0 & 10984.62 & \\
\hline & MOP (00:00:60) & 49.23 & 16.0 & 787.69 & \\
\hline & Ferrous sulfate $(0.25 \%)$ & 3.00 & 364.0 & 1092.0 & \\
\hline \multirow{5}{*}{$75 \%$ of RDN $+0.25 \%$ Ferrous sulfate $\left(T_{2}\right)$} & Urea (46:00:00) & 100.00 & 6.0 & 600.00 & \multirow[t]{5}{*}{31864.31} \\
\hline & NPK $(20: 20: 20)$ & 80.00 & 230.0 & 18400.00 & \\
\hline & MPK (00:52:34) & 30.77 & 357.0 & 10984.62 & \\
\hline & MOP (00:00:60) & 49.23 & 16.0 & 787.69 & \\
\hline & Ferrous sulfate $(0.25 \%)$ & 3.00 & 364.0 & 1092.0 & \\
\hline \multirow[t]{5}{*}{$50 \%$ of RDN $+0.25 \%$ Ferrous sulfate $\left(\mathrm{T}_{3}\right)$} & Urea (46:00:00) & 8.70 & 6.0 & 52.17 & \multirow[t]{5}{*}{31316.48} \\
\hline & NPK (20:20:20) & 80.00 & 230.0 & 18400.00 & \\
\hline & MPK (00:52:34) & 30.77 & 357.0 & 10984.62 & \\
\hline & MOP (00:00:60) & 49.23 & 16.0 & 787.69 & \\
\hline & Ferrous sulfate $(0.25 \%)$ & 3.00 & 364.0 & 1092.0 & \\
\hline \multirow[t]{6}{*}{$75 \%$ of RDN $+0.25 \%$ Ferrous sulfate $+0.2 \%$ Borax $\left(T_{4}\right)$} & Urea (46:00:00) & 100.00 & 6.0 & 600.00 & \multirow[t]{6}{*}{33088.31} \\
\hline & NPK $(20: 20: 20)$ & 80.00 & 230.0 & 18400.00 & \\
\hline & MPK (00:52:34) & 30.77 & 357.0 & 10984.62 & \\
\hline & MOP (00:00:60) & 49.23 & 16.0 & 787.69 & \\
\hline & Ferrous sulfate $(0.25 \%)$ & 3.00 & 364.0 & 1092.0 & \\
\hline & Borax $(0.2 \%)$ & 2.40 & 510.0 & 1224.0 & \\
\hline \multirow{5}{*}{$100 \%$ of RDN $+0.5 \%$ Ferrous sulfate $\left(T_{5}\right)$} & Urea (46:00:00) & 191.30 & 6.0 & 1147.83 & \multirow[t]{5}{*}{33504.13} \\
\hline & NPK (20:20:20) & 80.00 & 230.0 & 18400.00 & \\
\hline & MPK (00:52:34) & 30.77 & 357.0 & 10984.62 & \\
\hline & MOP (00:00:60) & 49.23 & 16.0 & 787.69 & \\
\hline & Ferrous sulfate $(0.5 \%)$ & 6.00 & 364.0 & 2184.0 & \\
\hline \multirow{4}{*}{$75 \%$ of RDN $+0.5 \%$ Ferrous sulfate $\left(\mathrm{T}_{6}\right)$} & Urea (46:00:00) & 100.00 & 6.0 & 600.00 & \multirow[t]{4}{*}{32956.31} \\
\hline & NPK (20:20:20) & 80.00 & 230.0 & 18400.00 & \\
\hline & MPK (00:52:34) & 30.77 & 357.0 & 10984.62 & \\
\hline & MOP (00:00:60) & 49.23 & 16.0 & 787.69 & \\
\hline
\end{tabular}




\begin{tabular}{|c|c|c|c|c|c|}
\hline & Ferrous sulfate $(0.5 \%)$ & 6.00 & 364.0 & 2184.0 & \\
\hline \multirow{5}{*}{$50 \%$ of RDN $+0.5 \%$ Ferrous sulfate $\left(\mathrm{T}_{7}\right)$} & Urea (46:00:00) & 8.70 & 6.0 & 52.17 & \multirow[t]{5}{*}{32408.48} \\
\hline & NPK $(20: 20: 20)$ & 80.00 & 230.0 & 18400.00 & \\
\hline & MPK (00:52:34) & 30.77 & 357.0 & 10984.62 & \\
\hline & MOP (00:00:60) & 49.23 & 16.0 & 787.69 & \\
\hline & Ferrous sulfate $(0.5 \%)$ & 6.00 & 364.0 & 2184.0 & \\
\hline \multirow{6}{*}{$75 \%$ of RDN $+0.5 \%$ Ferrous sulfate $+0.2 \%$ Borax $\left(T_{8}\right)$} & Urea (46:00:00) & 100.00 & 6.0 & 600.00 & \multirow[t]{6}{*}{34180.31} \\
\hline & NPK (20:20:20) & 80.00 & 230.0 & 18400.00 & \\
\hline & MPK (00:52:34) & 30.77 & 357.0 & 10984.62 & \\
\hline & MOP (00:00:60) & 49.23 & 16.0 & 787.69 & \\
\hline & Ferrous sulfate $(0.5 \%)$ & 6.00 & 364.0 & 2184.0 & \\
\hline & Borax $(0.2 \%)$ & 2.40 & 510.0 & 1224.0 & \\
\hline \multirow[t]{3}{*}{ Control $\left(\mathrm{T}_{9}\right)$} & Urea (46:00:00) & 283.55 & 6.0 & 1701.32 & \multirow[t]{3}{*}{10118.71} \\
\hline & DAP (18:46:00) & 208.70 & 25.0 & 5217.39 & \\
\hline & MOP (00:00:60) & 200.00 & 16.0 & 3200.00 & \\
\hline
\end{tabular}

(*The calculation is based on one hactare land)

Table.1b Expenditure cost (intercultural operation) of peach cv. Shan-e-Punjab using different fertigation level and foliar applications

\begin{tabular}{|c|c|c|c|c|}
\hline \multicolumn{2}{|l|}{ Operations } & Labour engaged & Rate per day (Rs.) & Total costs (Rs.) \\
\hline \multicolumn{2}{|l|}{ Pruning } & 75 & 250.00 & 18750.00 \\
\hline \multicolumn{2}{|c|}{ Ring preparation } & 10 & 250.00 & 2500.00 \\
\hline \multirow[t]{2}{*}{ Fertilization } & Fertigation & 40 & 250.00 & 10000.00 \\
\hline & Control & 08 & 250.00 & 2000.00 \\
\hline \multicolumn{2}{|l|}{ Irrigation } & 50 & 250.00 & 12500.00 \\
\hline \multicolumn{2}{|l|}{ Spraying } & 12 & 250.00 & 3000.00 \\
\hline \multicolumn{2}{|l|}{ Weeding } & 50 & 250.00 & 12500.00 \\
\hline \multicolumn{2}{|l|}{ Tractor } & 04 & 250.00 & 1600.00 \\
\hline \multicolumn{2}{|l|}{ Harvesting } & 20 & 250.00 & 5000.00 \\
\hline \multicolumn{2}{|c|}{ Electricity (50 hours) } & - & 150.00 & 7500.00 \\
\hline & & & Total & $\begin{array}{l}73350.00 \text { (Excluding control) } \\
65350.00 \text { (Control) }\end{array}$ \\
\hline
\end{tabular}

(*The calculation is based on one hactare land) 
Table.2 Economics of the experiment using different variables in peach cv. Shan-e-Punjab during experimental years

\begin{tabular}{|c|c|c|c|c|}
\hline Treatments & Total expenditure (Rs.) & Yield (tonne) & Gross income (Rs.) & Net income (Rs.) \\
\hline $100 \%$ of RDN $+0.25 \%$ Ferrous sulfate $\left(T_{1}\right)$ & 105762.14 & 6.62 & 331000.00 & 225237.86 \\
\hline $75 \%$ of $\mathrm{RDN}+0.25 \%$ Ferrous sulfate $\left(\mathrm{T}_{2}\right)$ & 105214.31 & 7.28 & 364000.00 & 258785.69 \\
\hline $50 \%$ of $\mathrm{RDN}+0.25 \%$ Ferrous sulfate $\left(\mathrm{T}_{3}\right)$ & 104666.48 & 5.03 & 251500.00 & 146833.52 \\
\hline $75 \%$ of RDN $+0.25 \%$ Ferrous sulfate $+0.2 \%$ Borax $\left(T_{4}\right)$ & 104666.48 & 8.91 & 445500.00 & 340833.52 \\
\hline $100 \%$ of RDN $+0.5 \%$ Ferrous sulfate $\left(T_{5}\right)$ & 106854.13 & 6.95 & 347500.00 & 240645.87 \\
\hline $75 \%$ of RDN $+0.5 \%$ Ferrous sulfate $\left(\mathrm{T}_{6}\right)$ & 106306.31 & 7.69 & 384500.00 & 278193.69 \\
\hline $50 \%$ of RDN $+0.5 \%$ Ferrous sulfate $\left(\mathrm{T}_{7}\right)$ & 105758.48 & 5.28 & 264000.00 & 158241.52 \\
\hline $75 \%$ of RDN $+0.5 \%$ Ferrous sulfate $+0.2 \%$ Borax $\left(\mathrm{T}_{8}\right)$ & 107530.31 & 10.61 & 530500.00 & 422969.69 \\
\hline Control $\left(\mathrm{T}_{9}\right)$ & 75468.71 & 3.35 & 167500.00 & 92031.28 \\
\hline $\mathrm{CD}$ at $5 \%$ & - & 0.51 & - & - \\
\hline
\end{tabular}

(*The calculation is based on one hactare land) 
In the present investigation higher economics was reported under treatment $\mathrm{T}_{8}$ followed by $\mathrm{T}_{4}$. The trend obtained might be due to the fact that in treatments, $\mathrm{T}_{8}$ and $\mathrm{T}_{4}$ higher yield and consequently, higher income was obtained. On the other hand, lowest income obtained under $\mathrm{T}_{9}$, which is attributable to least performance of trees under study because of improper fertilization management in conventional method.

The similarly findings of higher benefit: cost ratio (1.53 and 2.91) with fertigation treatments of $75 \%$ recommended dose of fertilizer (RDF) was reported in papaya (Sadarunnisa et al., 2010) and guava (Ramniwas et al., 2013) orchards. Further, in high density orchard of citrus, higher benefit: cost ratio (2.47) was obtained with fertigation of $60 \%$ RDF [9]. The more or less similar observations were also made in kiwifruit (Chauhan and Chandel, 2008) and pomegranate (Haneef et al., 2014) field using different fertigation treatments.

In conclusion, the study has revealed that investment in peach orchards is an economically profitable, financially viable and socially acceptable business in study area. A positive correlation has also been observed between the different treatments and net income. Hence, to achieve the target of fruits production, priority should be given to proper fertilization management, including scheduling, optimum rate and use of fertigation with respect to conventional methods to minimize fertilizer as well as water losses and provide remunerative prices to the peach growers in Tarai regions of Uttarakhand. Therefore, to enhance peach production, there is a need to adopt such a smarter and efficient technology for fetching higher returns without affecting the physical and chemical properties of soil, from same piece of land.

\section{References}

Anonymous, 2016. Food and agriculture organization of the United Nations. FAOSTAT, statistics database, Rome, Italy.

Bussi, C., Huguet, J.G. and Defranc, H. 1991. Fertilization scheduling in peach orchards under trickle irrigation. Journal of Horticulture Science, 66: 487-493.

Chauhan, N. and Chandel, J.S. 2008. Effect of fertigation on growth, yield, fruit quality and fertilizer use efficiency of kiwifruit (Actinidia deliciosa). Indian Journal of Agricultural Sciences, 78: 389-93.

Gangwar, L.S., Singh, D. and Mandal, G. 2008. Economic Evaluation of peach cultivation in north Indian plains. Agricultural Economics Research Review, 21: 123-129.

Gomez, K.A. and Gomez, A.A. 1984. Statistical procedure for Agricultural research, John Willey and sons, New York.

Gupta, P., Bhat, D., Wali, V.K., Bakshi, P., Bhat, A. and Jasrotia, A. 2016. Cost and return analysis of different treatments of mulching and herbicide application on peach (Prunus persica (L.) Batsch) cv. Shan-e-Punjab. Economic Affairs, 61(3): 481-486.

Haneef, M., Kaushik, R.A., Sarolia, D.K., Mordia A. and Dhakar, M. 2014. Irrigation scheduling and fertigation in pomegranate cv. Bhagwa under high density planting system. Indian Journal of Horticulture, 71(1): 45-48.

Nirgude, V., Karuna, K., Patel, V.B., Pal, A.K., Singh, M. and Homa, F. 2017. Effect of NPK fertigation on leaf nutrient status and yield of Citrus sinensis Osbeck cv. mosambi under high density planting. Environment and Ecology, 35(4C): 3154-3157. 
Ramniwas, Kaushik, R.A., Pareek, S., Sarolia, D.K. and Singh, V. 2013. Effect of drip fertigation scheduling on fertilizer use efficiency, leaf nutrient status, yield and quality of 'Shweta' guava (Psidium guajava L.) under meadow orcharding. National Academy Science Letters, 36(5): 483-488.

Sadarunnisa, S., Madhumathi, C., Hari Babu,
K., Sreenivasulu, B. and Rama Krishna, M. 2010. Effect of fertigation on growth and yield of papaya cv. Red Lady. Acta Horticulturae, 851: 395-399.

Singh, Y., Singh, C.S., Singh, A., Singh, A.K. and Singh, K. 2005. Fertigation: A key for hi-tech. agriculture. Agriculture Water Management, 52: 128-149.

\section{How to cite this article:}

Vishal Nirgude, P.N. Singh, K.K. Misra, A.K. Singh, P.C. Srivastava and Atul Kumar. 2018. Study on Economics of Peach Cultivation under Different Fertigation Level and Foliar Applications in Tarai region of Uttarakhand, India. Int.J.Curr.Microbiol.App.Sci. 7(08): 36123619. doi: https://doi.org/10.20546/ijcmas.2018.708.365 